\title{
PEMIKIRAN POLITIK IBNU TAIMIYAH
}

\author{
QAMARUZZAMAN \\ STAI MEMPAWAH KALIMANTAN BARAT \\ qamaruzzaman@gmail.com
}

\begin{abstract}
Abstrak
Tulisan ini membahas tentang pemikiran politik Ibn Taimiyah dalam sejarah politik Islam serta kontekstualisasinya di masa sekarang. Pertanyaan mendasar dalam kajian ini adalah tentang bagaimana bentuk sistem politik dan kenegaraan yang ditawarkan oleh Ibn Taimiyah, dan apakah teorinya masih relevan dengan kondisi sosial-politik saat ini. Ibn Taimiyah dengan keberaniannya menghapuskan/penolakan sistem kepemimpinan Khilafah dan Imamah, dengan tesisnya yang mengatakan bahwa rejim yang ditegakkan nabi adalah rejim nubuwwah dan bukan imamah, sedang imamah baru ada setelah nabi wafat menunjukkan bahwa ia mempunyai gagasan yang revolusioner dan pembaruan. Ia tidak ingin rakyat hanya menjadi objek dalam sebuah negara tapi Ia ingin rakyat menjadi subjek atas negara. Bagi Ibn Taimiyah, mekanisme/sistem pengangkatan kepala negara tidak terlalu penting, yang penting adalah bahwa orang yang menduduki jabatan itu harus benar-benar amanah dan adil. Ibn Taimiyah mensyaratkan dua hal bagi kepala negara, yaitu memiliki kualifikasi kekuatan (alquwwah) dan integritas (al-amanat). Kekuatan dan integritas tersebut diperoleh melalui cara mubaya'ah (sumpah setia) yang diberikan oleh ahl al-Syawkah.
\end{abstract}

Kata Kunci : Pemikiran Politik Islam, Ibn Taimiyah, Dekonstruksi Khilafah

\section{A. Pendahuluan}

Teori Ibn Taimiyah tentang pemerintahan merupakan contoh kritik yang dapat dikatakan meremehkan teori khilafah. Dasar pijakan kritiknya adalah penolakan terhadap pandangan yang menyebutkan bahwa kekhalifahan tidak mempunyai dasar konstitusional dari al-Quran. Al-Quran memang secara khusus menjelaskan kebutuhan terhadap pemerintahan dan kekuasaan, ${ }^{1}$ tetapi tidak

${ }^{1}$ Dalam salah satu karyanya di bidang politik yang monumental adalah As-siyasah Asy-Syariyyah fi Ishlahi Ar-ra'i wa Ra'iyah (Politik Ketatanegaran menurut Islam Guna Perbaikan Pemimpin dan Rakyat) di sebutkan bahwa Ibnu Taimiyyah mendasarkan pembahasan tentang butuhnya kekuasaan pada surat An-Nisa (4):58-59: 
memaparkan secara rinci keputusan konstitusional pemerintahan Islam. Jadi, di dalam al-Quran dan as-Sunnah tidak terdapat dasar pijakan bagi keputusan konstitusional baku yang melandasi teori khilafah.

Dengan penolakan tersebut, Ibn Taimiyah ingin menawarkan sebuah alternatif pemikiran. Bahwa persoalan pokok dalam teori Islam bukanlah pada lembaga khilafah, tetapi pada hukum syariat. Meskipun khilafah dikatakan berpijak pada syariat, namun perkembangan sejarah lembaga tersebut satusatunya organisasi politik yang diterima dalam Islam justru menghantarkannya pada legitimasi tertentu yang tidak lagi sejalan dengan ajaran-ajaran pokok syariat. Dalam Islam, negara memiliki peranan penting (instrumental) untuk meraih tujuan-tujuan syariat, sebagaimana terungkap dalam al-Quran dan as-Sunnah. Ibn Taimiyah menghendaki terwujudnya pemerintahan yang menitikberatkan pada asas konstitusi dan hubungan perjanjian melalui proses pemilihan pemimpin.

Menjadi pertanyaan mendasar yang akan dibahas dalam makalah ini adalah bagaimanakah sistem politik dan kenegaraan yang ditawarkan oleh Ibn Taimiyah, dan apakah teorinya masih relevan dengan kondisi sosial-politik saat ini?

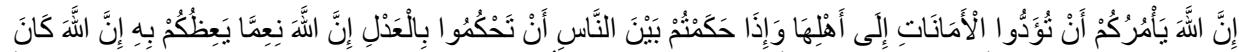

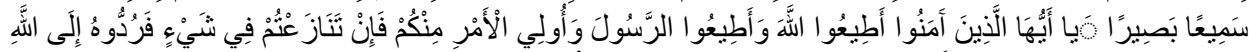

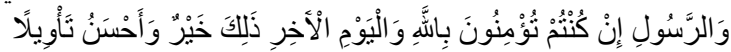

Ayat pertama diturunakan untuk para pemimpin, yakni agar senantisa mereka menunaikan amanat kepada yang berhak, dan bila mereka menjatuhkan suatu hukum agar berlaku adil. Ayat kedua diturunkan kapada rakyat, tentara dan lainnya. Mereka wajib mentaati pemimpin yang bertindak adil, kecuali bila pemimpn itu memerintahkan kemaksiatan. 


\section{B. Riwayat Hidup Ibn Taimiyah}

Ibn Taimiyah adalah tokoh abad XIV (1263-13280. ${ }^{2}$ Nama lengkapnya ialah Ahmad Taqiy ad-Dĩn Abu al-Abbās ibn Syihab ad-Dĩn Abĭ al-Mahāsin Abd asSalām ibn Abĩ Muhammad Abd. Allah ibn Abǐ al-Qasĩm al-Khudr ibn Muhammad ibn al-Khudr ibn Alĩ ibn Abd. Allah³, atau yang lebih dikenal dengan Taqiyuddin Ahmad Ibn Taimiyyah, ${ }^{4}$ lahir pada hari senin 10 Rabiul Awwal 661 H./22 januari 1263 M. di Harran Syria. ${ }^{5}$

Ibn Taimiyah lahir dari sebuah keluarga terpelajar dan sangat dihormati oleh masyarakat luas pada masanya. Ayahnya, Syihăb al-Dĩn Abd Halĩm ibn Abd as-Salăm 9627-682 H.) merupakan seorang ulama besar yang menjadi khatib, imam besar, guru tafsir dan hadis di Masjid Agung Damaskus, serta juga menjadi direktur Madrasah Dăr al-Hadist al-Sukkariyyah, salah satu lembaga pendidikan Islam mazhab Hambali yang sangat maju dan bermutu pada masannya. Kakeknya, syekh Majd ad-Dĩn Abi al-Barakat Abd as-Salăm ibn Abd Allah (590-652 H.) juga seorang mujtahid mutlak, mufassir, ahli hadis, ahli ushul fiqh, ahli nahwu, dan pengarang. ${ }^{6}$ Pamannya dari pihak bapak, Syarf ad-Dĩn Abd Allah ibn Abd al-Halim adalah seorang cendekiawan Muslim populer dan pengarang yang produktif pada

${ }^{2}$ Husayn Ahmad Amin, al-Mi'ah al-A'zham fi Tarikh al-Islam. Cucu Cuanda (ed.) Seratus Tokoh dalam Sejarah Islam (Bandung: Remaja Rosdakarya, cet. 7, 2001), hlm. 229.

3 Keluarganya dinasabkan dengan nama Taimiyah, karena sewaktu kakeknya, Muhammad ibn Khudr melakukan perjalanan haji melewati jalan Taima' bertemu dengan seorang anak perempuan bernama Taimiyah. Dan sekembalinya dari haji, istrinya melahirkan anak perempuan yang diberi nama Taimiyah. Menurut sumber lain mengatakan, bahwa pemberian nama Taimiyah dinisbatkan pada nama ibu kakeknya Muhammad al-Khudr yang berprpfesi sebagai muballighah.

4 Qomaruddin Khan, The Political Thought of Ibn Taymiyyah., terj. Anas Wahyuddin, Pemikiran Politik Ibnu Taymiyyah (Bandung : Pustaka, cet. 2, 2001), hlm.10.

${ }^{5}$ Ibn Katsir, al-Bidayah wa an-Nihayah, jilid IX juz 14, (Beirut Lebanon: Dar al-Fikr, t.th), hlm. 135-136. Lihat juga Muhammad Amin, Ijtihad Ibn Taimiyah dalam Bidang Fikih Islam, (Jakarta: INIS, 1991), hlm. 7.

${ }^{6}$ Jeje Abdul Rojak, Politik Kenegaraan Pemikiran al-Ghazali dan Ibn Taimiyah (Surabaya: Bina Ilmu, cet. 1, 1999), hlm. 116-117. 
masanya. Sedangkan adik laki-lakinya ternyata juga dikenal sebagai ilmuan Muslim yang ahli dalam bidang kewarisan Islam, ilmu-ilmu hadis dan ilmu pasti. ${ }^{7}$

Pada masa Ibn Taimiyah 5 tahun, Islam sedang mengalami kemunduran. Di sebelah Timur, kaum Muslimin (Baghdad) dijatuhkan dan dihancurkan tentara Mongol (Dinasti Chaghtai yang di pimpin Mubarak Syah), ${ }^{8}$ dan di sebelah Barat (Kristiani-Salib) mereka akhirnya terusir dari Spanyol. Akibatnya banyak kaum cerdik pandai mengungsi ke negeri-negeri yang lebih aman seperti ke Kairo dan Damaskus. Termasuk keluarga Ibn Taimiyah sendiri yang memilih ke Damaskus. Keluarga Ibn Taimiyah kemudian menjadi tokoh terkemuka karena pengabdian mereka kepada ilmu pengetahuan Islam. ${ }^{9}$

Ibn Taimiyah tidak hanya memperoleh pendidikan di madrasah ayahnya sendiri. Tetapi, ia juga belajar kepada sejumlah ulama terkemuka seperti Syams adDĩn Abd ar-Rahmăn ibn Muhammad ibn Ahmad al-Maqdisi, seorang faqih ternama dan Hakim Agung pertama dari kalangan mazhab Hambali di Syria, Muhammad ibn Abd al-Qawi ibn Badran al-Maqdisi al-Mardawi, seorang muhaddis, faqih, nahwiyy, dan mufti serta pengarang terpandang pada masanya, al-Manja' ibn Usman ibn asy-Syaibani. Selain itu, Ibn Taimiyah juga berguru kepada Zainab binti Makki al-Harrani, Syekh Syams ad-Din al-Asfihani asy-Syafi'i, Abd ar-Rahim ibn Muhammad al-Bagdadi, dan sejumlah ulama lain, baik yang terbilang kecil maupun tergolong besar, yang jumlahnya puluhan bahkan ratusan orang. ${ }^{10}$

Ibn Taimiyah menjadi mufti sejak sebelum berumur 21 tahun, ia mengabdikan ilmunya demi kepentingan Islam dan umat. Sewaktu ayahnya wafat pada tahun 682 H/1284 M., ia menggantikan jabatan ayahnya sebagai Direktur Madrasah Dăr al-Hadis as-Syukkariyah. Selain sebagai Direktur Madrasah, ia juga

${ }^{7}$ Amin, Ijtihad, hlm. 7-8.

8 Abdul Karim, Islam di Asia Tengah; Sejarah Dinasti Mongol-Islam (Yogyakarta: Bagaskara, 2006), hlm. 50.

${ }^{9}$ Khan, The Political, hlm. 12.

${ }^{10}$ Ibid, hlm. 9-10. 
menggantikan kedudukan ayahnya sebagai guru besar hadis dan fiqh Hambali di beberapa madrasah terkenal yang ada di Damaskus. ${ }^{11}$

Dalam hal keagamaan, pada masa Ibn Taimiyah terdapat empat mazhab fiqh besar yang dijadikan rujukan umat Islam. Yaitu mazhab Maliki (712-795 M.), Hanafi (699- 767 M), Syafi'I (767-820 M.), dan mazhab Hambali (780-855 M.). Dalam hal teologi, paham al-Asy'ari dan al-Maturidi sangat mendominasi. Pada masa itu pula, muncul banyak tokoh-tokoh mistik dengan akrobatik-akrobatik spiritual mereka yang terlampau yakin dengan penafsiran bid'ah mereka, taqlid mutlak di dalam masalah-masalah kepercayaan, di dalam metode pemahaman, dan di dalam menerima hukum-hukum syari'ah beserta kesimpulan-kesimpulannya. ${ }^{12}$ Dalam kondisi yang demikian Ibn Taimiyah mengumandangkan kebebasan berijtihad, dan anjuran untuk kembali kepada al-Qur'an, sunnah dan praktikpraktik as-salaf as-salih. Oleh sebab itu, maka konflik tidak bisa dihindarkan dengan para penentang-penentangnya yang tidak sepaham dengannya dan merasa terancam eksistensinya.

Aktifitas Ibn Taimiyah tidak hanya ceramah dan menulis, ia juga merupakan seorang pejuang. Sewaktu Mongol menyerang Damaskus, ia ikut dalam menghalau serangan itu, bahkan ia diminta oleh Gubernur Damaskus untuk pergi ke Kairo memohon bantuan Sultan An-Nashir untuk mengirim militer ke Syria melawan Mongol. Akhirnya pada tahun 1303 M. pasukan Mamluk ${ }^{13}$ Mesir-

\footnotetext{
${ }^{11}$ Amin., Ijtihad, hlm. 12.

${ }^{12}$ Khan, The Political, hlm. 5-6.
}

${ }^{13}$ Dinasti Mamalik atau Mamluk merupakan fenomena unik di dalam sejarah politik Islam. Kelahirannya berasal dari para budak yang berasal dari berbagai suku dan bangsa yang menciptakan suatu tatanan kekuatan militer di wilayah asing. Merekalah yang berhasil membebaskan Suriah dan Mesir yang sebelumnya dikuasai Tentara Salib. Selama beberapa waktu mereka pula yang berhasil menahan laju serangan bangsa mongol yang dipimpin oleh Hulagu dan Timur Lenk. Seandainya mereka gagal bertahan, tentu tatanan sejarah dan kebudayaan Asia Barat dan Mesir yang memiliki akar Islam berubah drastis. Dinasti Mamluk menguasai satu kawasan paling "panas" di dunia dan memelihara keutuhan wilayah tersebut meskipun mereka terdiri dari ras yang berbeda-beda. Lihat, http: //aliboron. wordpress. com/2010/10/26/pemikiran-politik-ibnu-taimiyah 
Syria berhasil memenangkan pertempuran. Keberhasilan tersebut membuat namanya populer dan dihormati oleh rakyat dan pemerintah. ${ }^{14}$

Konflik awal dalam masalah keagamaan antara Ibn Taimiyah dan para penentangnya adalah ketika orang-orang Hamah meminta pendapat (fatwa)nya mengenai sifat-sifat Allah yang disebutkan di dalam al-Qur'an. Ibn Taimiyah memberikan jawaban dalam bentuk risalah yang berjudul ar-Risalah al-Hamawiyah. Risalah inilah yang memicu protes para fuqaha yang diketuai Qadhi Jalaluddin dari mazhab Hanafi di Damaskus. Ibn Taimiyah dihadapkan kepada para hakim dan ahli hukum terkemuka untuk mempertanggungjawabkan fatwa tersebut. Terjadilah perdebatan sengit yang akhirnya dimenangkan oleh Ibn Taimiyah. Peristiwa ini merupakan awal dari konflik intelektual yang seru di kemudian hari. ${ }^{15}$

Sementara awal konflik Ibn Taimiyah dalam masalah politik adalah ketika ia memprotes keras keputusan pemerintah (Gubernur Syria) yang tidak menjatuhkan hukuman mati kepada Assaf an-Nasrani, seorang Kristen berkebangsaan Suwayda', padahal Assaf telah menghina Nabi Muhammad Saw. Hanya karena Assaf mau memeluk agama Islam ketimbang dijatuhi hukuman mati. Menurut Ibn Taimiyah, siapapun yang telah menghina Rasulullah, tidak peduli ia Muslim atau bukan, harus dihukum mati. Karena protes dan sikap

${ }^{14}$ Ibid.

${ }^{15}$ Konflik selanjutnya misalnya dengan kaum sufi yang disponsori Ibn 'Ata' asSukandari. Untuk mengetahui komentar-komentar penentangnya, penulis kutipkan pernyataan al-ustadz Abdul Ghani Hamadah. Ia menyatakaan bahwa orang-orang ahli bid'ah mengagungkan dirinya sendiri. Mereka berkata kami adalah penolong sunnah, kami salafiyun, kami mujaddidun sebagaimana yang dikatakan oleh guru mereka, Ibn Taimiyah. Padahal sebenarnya merekalah ahli bid'ah dari golongan yang sesat, karena 1) penyimpangan mereka dari imam mazhab yang empat dan dari jumhur ulama kaum Muslimin, 2) paham antrophomorpisme/tajsim mereka terhadap sifat-sifat Allah, dan 3) mengkafirkan ulama-ulama dan auliya terkemuka. Hamadah juga mengutip komentarkomentar ulama mengenai diri Ibn Taimiyah, mislanya 'Alauddin al-Bukhari mengatakan bahwa Ibn Taimiyah kafir, Zainuddin al-Hambali menyebutnya kafir, imam as-Subki mengkafirkan Ibn Taimiyah karena ia telah mengkafirkan umat Islam dan menyerupakan mereka dengan kaum Yahudi dan Nasrani di dalam tafsirnya, Ibn Hajar menyebut Ibn Taimiyah sebagai hamba yang ditelantarkan, disesatkan, dibutakan, dibisukan, dan dihinakan Allah dan komentar-komentar ulama lainnya. Lihat al-Ustadz Abdul Ghani Hamadah, Fadh al-Dzakirin wa al-Raddu 'Ala al-Munkirin (Suria: t.p., 1971), hlm. 22-23. 
tegasnya itu akhirnya Ibn Taimiyah harus meringkuk di dalam penjara 'Adrawiyyah di Damaskus. ${ }^{16}$

Puncak dari keseluruhan kebencian terhadap Ibn taimiyah terjadi 2 tahun sebelum meninggal. Musuh-musuhnya menggali fatwa-fatwa ziarah kubur yang pernah dikeluarkannya. Akibatnya muncul reaksi dari publik termasuk dari sultan sendiri. Pada akhirnya Ibn Taimiyah dipenjarakan lagi. Walaupun begitu, tidak menghentikan kegiatannya menulis hingga akhirnya seluruh bahan bacaan dan tulisan dirampas dari tangannya. Saat itulah dia ia baru berhenti menulis, dan beberapa waktu kemudian menghembuskan nafasnya yang terakhir di penjara damaskus dalam usia 65 tahun, tepatnya pada malam senin, 20 Zulkaidah 728 H/26 September 1328 M. $^{17}$

\section{Konsep Negara dan Kepemimpinan Negara Ibn Taimiyah}

Pemikir-pemikir Muslim memandang masalah konsep Negara dan kepemimpinan negara dalam bentuk yang berbeda-beda. Kaum Sunni menyatakan bahwa menegakkan negara (imamah) bukanlah salah satu asas dan praktik agama seperti yang diyakini oleh orang-orang Syi'ah. Menurut mereka, imamah adalah salah satu dari detail-detail (furu') yang berhubungan dengan perbuatan orangorang beriman, karena menurut pendapat mereka, kepada ummah diperintahkan untuk mengangkat seorang imam melalui al-sam' (tradisi). ${ }^{18}$ Yang dimaksud dengan al-sam', menurut Qomaruddin Khan, adalah al-Qur'an , sunnah dan ijma' (konsensus). ${ }^{19}$ Pandangan golongan Mu'tazilah sangat bertentangan dengan pandangan Sunni. Mu'tazilah berpendapat bahwa keharusan menegakkan imamah dapat dibuktikan oleh akal pikiran. ${ }^{20}$ Sementara golongan Syi'ah juga menolak akal

\footnotetext{
${ }^{16}$ Amin, Ijtihad, hlm. 13.

${ }^{17}$ M. Arskal Salim G.P, Etika Intervensi Negara (Jakarta: Ligos, 1998), hlm. 44.

18 Ibn Taimiyah, Minhaj al-Sunnah al-Nabawiyah fi Naqd Kalam al-Syi'ah wa al-
} Qadariyah, jilid 1 (Kairo: Maktabah Dar al-'Urubat, 1962), hlm. 26.

${ }^{19}$ Khan, The Political,hlm. 48.

${ }^{20} \mathrm{Ibid}, \mathrm{hlm} .29$. 
pikiran karena dianggap tidak mencukupi. Mereka berpendapat bahwa imamah adalah "luthf" (berkah) Allah kepada hamba-hamba-Nya. ${ }^{21}$

Ibn Taimiyah sendiri lebih sependapat dengan Sunni. Ia menyatakan bahwa mengatur urusan umat termasuk kewajiban-kewajiban agama yang sangat terpenting. Tetapi tidak berarti agama tidak bisa tegak tanpa adanya negara. Kepentingan manusia, menurutnya, tidak bisa terpenuhi kecuali dengan bergabung menjadi suatu masyarakat, mengumpulkan kepentingan satu sama lain. Ketika berkumpul maka harus ada pemimpin. Argumen rasional itu juga diperkuat oleh beberapa landasan Sunnah Nabi saw. Contohnya adalah sabda Nabi yang bila ada tiga orang melakukan perjalanan, maka salah seorang di antara mereka selayaknya menjadi pemimpin. ${ }^{22}$ Ibn Taimiyah tidak mendasarkan pada metode ijma' sebagai alasan kewajiban mendirikan negara. Tetapi ia lebih menekankan kepada upaya mewujudkan kesejahteraan umat manusia (maslahah) dan melaksanakan syariat Islam (iqămat al-Syari'ah al-Islămiyyah). Agama yang memiliki seperangkat hukum, perintah dan larangan, Allah memerintahkan manusia supaya melaksanakan amar ma'ruf dan meninggalkan kejahatan, jihad, keadailan, ibadah haji, bermasyarakat yang teratur, menolong orang yang teraniaya dan lain-lain. Semuanya tidak bisa terlaksana dengan baik, kecuali dengan adanya kekuasaan dan pemimpin. Ibn Taimiyah menegaskan bahwa mengatur orang banyak adalah kewajiban agama. Dengan demikian, sebetulnya ia menganggap tidak penting sistem khilafah, institusi khilafah boleh ditiadakan. ${ }^{23}$

Ibn Taimiyah berpendapat, bahwa manusia merupakan jenis makhluk yang saling memerlukan sesamanya guna mencukupi segala kebutuhannya. Tidak mungkin dengan seorang diri manusia dapat memenuhi kebutuhan hidupnya tanpa adanya kebutuhan atau berdampingan dengan adanya orang lain. Karena

${ }^{21}$ Ibid, hlm. 55.
${ }_{22}$ Ibn Taimiyah, al-Siyasah al-Syar'iyah fi Ishlahi al-Ra'i wa al-Ra'iyyah (Beirut Lebanon: Dar al-Kutub al-Ilmiyah, 1409H/1988M), hlm. 172-173.

${ }^{23}$ Ibid. 
itu, satu sama lain saling membutuhkan untuk mendapatkan kebutuhan hidup. Keinginan untuk mencukupi kebutuhan agar bertahan hidup, dan untuk memperolehnya memerlukan kerja sama, mendorong mereka berkumpul disuatu tempat agar mereka saling tolong menolong dan memberi. Proses itulah, menurutnya yang membawa terbentuknya kota-kota, dan akhirnya menjadi negara. $^{24}$

Dengan begitu, menurut Ibn Taimiyah, menegakkan pemerintahan adalah kewajiban agama, bukan karena pertimbangan konsensus (ijma'). Sekalipun ia juga mengakui bahwa kerja sama dan tolong-menolong merupakan sendi bermasyarakat, akan tetapi perintahnya bukan semata-mata atas pertimbangan kesepakatan, melainkan atas dasar perintah Allah, agar saling tolong-menolong dalam kebajikan dan tidak dalam berbuat dosa dan kejahatan. ${ }^{25}$

Mengenai bentuk kepemimpinan negara/pemerintahan, Ibn Taimiyah berpendapat bahwa membentuk imarah (kepemimpinan) adalah kewajiban asasi dalam agama, alasan yang dikemukakan adalah bahwa upaya menegakkan agama dan mencapai kemaslahatan bagi segenap manusia mustahil dapat direalisasikan tanpa adanya suatu perkumpulan (kepemimpinan) yang bersifat mengikat dan dapat memenuhi kebutuhan mereka. ${ }^{26}$ Ibn Taimiyah sangat menekankan keharusan menegakkan kepemimpinan negara untuk membela agama, karena ia benar-benar yakin bahwa tujuan Islam adalah menciptakan suatu tertib sosial, di mana nilai-nilai dasar al-Qur'an dan as-Sunnah direalisir. Tata sosial seperti ini tidak dapat terealisir secara ideal tanpa negara. Itulah sebabnya mengapa Ibn

${ }^{24}$ Rojak, Politik, hlm.165.

${ }^{25}$ Al-maidah (5);2.

${ }^{26}$ Rojak, Politik, hlm.165. 
Taimiyah pernah menyatakan bahwa agama tidak akan mungkin hidup tanpa negara. $^{27}$

Ibn Taimiyah memandang bahwa kedudukan kepala Negara sebagai jabatan amanah. Meski ia tidak secara tegas merumuskan mikanisme pengangkatan kepala Negara tersebut, akan tetapi dalam bukunya (sebagaimana dikutip oleh Jeje Abdul Rojak) at-Tibr al-Masbuk fi Nasihat al-Mulk menyebutkan, bahwa sebetulnya tidak terlalu penting membicarakan sistem pengangkatan kepala negara, yang penting adalah orang yang menduduki jabatan itu harus benar-benar orang yang dapat menunaikan amanah dan menciptakan keadilan. ${ }^{28}$

Menurut Ibn Taimiyah, sebagai faktor instrumental dalam mewujudkan kesejahteraan bersama, adanya seorang kepala negara merupakan sesuatu yang niscaya dan tidak terelakkan. Di sini prinsip gagasannya adalah bahwa kaum muslim dalam hidup sosial perlu ada pemimpin dan diorientasikan pada stabilitas. Dasar pandangan ini dikatakan berasal dari Rasulullah Muhammad yang bersabda bahwa 70 (tujuh puluh) tahun kehidupan sosial di bawah kekuasaan refresif masih lebih baik dari hidup sosial tanpa ada kepemimpinan atau (lebih baik) dari anarkhi. Dari sumber lain pernyataan "Lebih baik 60 (enam puluh) tahun diperintah oleh pemimpin yang dzalim dibandingkan hidup satu hari tanpa pemerintahan (chaos/vacuum of power)". ${ }^{29}$ Untuk memahami pernyataan ini bukan secara harfiahnya demikian. Akan tetapi adalah betapa pentingnya adanya pemimpin. Jadi dalam pandangan Ibn Taimiyah seandainya dibedakan antara seorang pemimpin dan syarat-syarat yang harus dimilikinya, maka keberadaan

27 Ibnu Taimiyah, Siyasah Syar'iyah: Etika Politik Islam" Terj. Rafi' Munawar ( Surabaya : Risalah Gusti, 2005) hlm. 27-28.

${ }^{28}$ Rojak, Politik, hlm. 164.

29 Disebutkan bahwa Allah menolong pemerintahan yang adil walaupun yang dimiliki oleh orang-orang kafir dan tidak menolong pemerintahan yang sewenang-wenang walaupun yang dimiliki oleh orang-orang Muslim. Riwayat yang lain menyebutkan bahwa sehari bersama seorang pemimpin yang adil itu lebih utama daripada beribadah enam puluh tahun. Lihat Ibn Taimiyah, al-Siyasah, hlm. 22. 
seorang pemimpin Negara merupakan keharusan yang tidak bisa ditawar-tawar lagi.

\section{Pengangkatan Kepala Negara}

Ibn Taimiyah tidak secara tegas merumuskan mekanisme pengangkatan kepala negara. Dia hanya menyebutkan bahwa sebetulnya tidak terlalu penting membicarakan sistem pengangkatan kepala negara. Menurutnya, yang penting adalah bahwa orang yang menduduki jabatan itu harus benar-benar amanah dan adil. Karena pentingnya dua hal ini, sehingga di awal bukunya, al-Siyasah alSyariyah, ia secara khusus membahas doktrin amanah dan keadilan bagi mereka yang menduduki jabatan. Ibn Taimiyah mensyaratkan dua hal bagi kepala negara, yaitu memiliki kualifikasi kekuatan (al-quwwah) dan integritas (al-amanat). ${ }^{30}$

Kekuatan dan integritas ini menurut Ibn Taimiyah diperoleh melalui cara mubaya'ah (sumpah setia) yang diberikan oleh ahl al-Syawkah ${ }^{31}$ yang efektif kepada raja/kepala negara. Ini berarti bahwa dukungan umat muncul sebagai akibat wajar dari bay'ah tersebut, bukan sebagai prosedur terpisah yang diperlukan itu sendiri.

\footnotetext{
${ }^{30} \mathrm{Ibid}, \mathrm{hlm} .20$.
}

31 Konsep ahl al-Syawkah yang dikemukakan oleh Ibn Taimiyah telah menghancurkan fiksi pemilihan suara dan institusi al-hall wa al-'aqd yang tidak terbentuk. Karena menurutnya, Negara tercipta melalui kerjasama di antara anggota-anggota masyarakat; dan penguasa tertinggi yang dipilih oleh rakyat memiliki kekuatan dan otoritas yang sesungguhnya di dalam masyarakat. Misalnya Abu Bakar yang berhak menjadi imam dan yang julukannya, menurut ahli-ahli tertentu, dapat pula dibuktikan dengan nash, hanya dapat jadi imam karena sumpah setia (mubaya'ah) kepadanya oleh orang-orang yang memiliki kekuatan. (ahl al-Syawkah). Dengan cara yang sama, Umar menjadi seorang imam setelah diangkat oleh Abu Bakar dan rakyat mengikrarkan kesetiaan kepadanya. Tetapi seandainya rakyat tidak menyetujui pengangkatan Abu bakar, dan mereka tidak menyatakan kesetiaan pada Umar maka Umar tidak dapat menjadi imam, betapa pun benar atau salahnya, karena kekuasaan dan otoritas ditentukan setelah kekuatan yang aktual direalisir. Atau jika Umar beserta beberapa orang lainnya telah mengikrarkan kesetiaan mereka kepada Abu Bakar dan sahabat-sahabat yang lain menolaknya, maka Abu Bakar tidak dapat menjadi Imam. Jadi pendapat yang menyatakan bahwa seseorang dapat menjadi imam oleh dukungan satu, dua, atau empat individu yang bukan ahl al-Syawkah adalah salah sama sekali (tidak ligitimete). Lihat Khan, The Political,hlm. 231-232. 
Mubaya'ah ini nantinya akan berfungsi menjadi semacam kontrak sosial yang mengikat antara raja/kepala negara dan rakyat. Sedangkan yang dimaksud ahl alSyawkah sendiri menurut Ibn Taimiyah adalah semua orang, tanpa memandang profesi dan kedudukan mereka, dihormati dan ditaati oleh masyarakat. ${ }^{32}$ Jadi menurutnya, khilafah tidak disyaratkan oleh sesuatu pun juga kecuali oleh dukungan ahl al-Syawkah, dan mengenai rakyat kebanyakan (jumhur) yang telah menolong berdirinya Negara, sesungguhnya mereka ini hanyalah alat untuk merealisir tujuan ummah. Rakyat kebanyakan memang ikut bekerjasama di dalam memperjuangkan tujuan-tujuan pokok negara, tetapi sehubungan dengan penegakan imamah hanya ahl al-Syawkah yang berkepentingan. ${ }^{33}$

Menurut Qomaruddin Khan hanya Ibn Taimiyahlah yang telah memberikan perspektif yang tepat kepada konsep syawkah ini. Ibn Taimiyah menolak teori tradisional mengenai kekhalifahan dan mengembangkan sebuah teori tersendiri mengenai kepemimpinan negara. Konsep atau teori ini pada gilirannya nanti ditransformasikan oleh Ibn Khaldun ke dalam teorinya yang terkenal mengenai 'asabiyah. ${ }^{34}$ Meskipun Ibn Taimiyah mensyaratkan dua hal kepada calon penguasa atau kepala negara, namun apabila penguasa atau kepala negara yang ideal (memiliki kualifikasi kekuatan dan integritas) tidak bisa diperoleh, menurut Ibn Taimiyah harus diangkat orang yang paling sesuai untuk pekerjaan itu. Tetapi, menurutnya hal itu hanya bersifat sementara, dan bahwa setelah itu kaum Muslim harus berusaha memperbaiki keadaan mereka supaya dapat memenuhi ajaran-ajaran Islam. ${ }^{35}$

Dalam hal penunjukan atau pengangkatan pembantu-pembantunya, Ibn Taimiyah berpendapat, bahwa seorang kepala negara harus berusaha mencari orang-orang yang secara objektif betul-betul memiliki kecakapan dan kemampuan

\footnotetext{
${ }^{32}$ Ibid,,hlm. 234.

${ }^{33}$ Ibid.

${ }^{34}$ Ibid, hlm. 235.

${ }^{35}$ Ibn Taimiyah, As-Siyasah, hlm. 13-21.
} 
untuk jabatan-jabatan tersebut, dan jangan karena terpengaruh faktor-faktor subjektif seperti hubungan kekeluargaan dan lain sebagainya. ${ }^{36}$

Ibn Taimiyah memaknai kata amanah dalam dua pengertian. Pertama, amanah diartikan kepentingan-kepentingan rakyat yang merupakan tanggung jawab kepala negara untuk mengelolanya. Kedua, amanah diartikan kewenangan pemerintah yang dimiliki oleh kepala negara. ${ }^{37}$ Dengan persyaratan yang demikian, maka Ibn Taimiyah tidak mensyaratkan calon kepala negara harus dari suku Quraisy. Persyaratan ini (suku Quraisy) bertentangan dengan al-Qur'an yang mengakui persamaan derajat sesama manusia, meskipun ada hadis yang dijadikan landasan terhadap persyaratan suku Quraisy tersebut. ${ }^{38}$

Konsep amanah dan keadilan di atas sangat mendominasi pemikiran politik Ibn Taimiyah, yang bedasarkan pada nilai-nilai agama. Seperti halnya ia dikenal sebagai pemikir muslim yang sangat kuat berpegang pada nas-nas alQur'an dan Hadits. Demikian pula pemikiran politiknya sangat kuat relevansinya dengan syari'at dan etik. Akan tetapi ketika menjabarkan term-term politiknya itu, pertimbangan kemaslahatan bersama terlihat sangat jelas ${ }^{39}$ misalnya ketika mengutip hadist bahwa sehari dipimpin oleh pemerintah yang zalim lebih baik dari pada enam puluh tahun vakum kekuasaan. Pernyataan seperti ini lebih memperhatikan kemaslahatan, stabilitas daripada chaos atau anarkhis sekalipun sama-sama mengundang kerawanan. Tapi kenyataan itu merupakan implementasi dari kaidah apabila terdapat dua kemudaratan maka harus dipilih yang lebih ringan resikonya. ${ }^{40}$ Kaedah ini adalah salah satu dari penerapan asas maslahat.

${ }^{36}$ Ibid.

${ }^{37}$ Munawir Sjadzali, Islam dan Tata Negara Ajaran, Sejarah dan Pemikiran, edisi 5 (Jakarta: UI Press, 1993), hlm. 85-86.

${ }^{38}$ Ibnu Taimiyah, al-Hisbah fi al-Islam au Wadifah al-Hukumah al-Islamiyah, (BeirutLibanon: Dar al-Kutub al-Ilmiyah, 1412 H/1992M), hlm 6-8.

${ }^{39}$ Ibnu Taimiyah, al-Hisbah, hlm .7.

${ }^{40}$ Abd al-Wahhab Khallaf, 'Ilmu Usul al-Fiqh (Kuwait: Dar al-Qalam,1397 H/1997 M), hlm. 208. 
Sebab pada hakekatnya maslahat itu merupakan tujuan agama dalam menata kehidupan.

Adapun mengenai tugas utama kepala negara menurutnya adalah menciptakan kemaslahatan bersama dalam wujud menjalankan amanah sebaikbaiknya dan menciptakan keadilan semaksimal mungkin. Dengan demikian, maka tujuan negara adalah 1) sebagai alat untuk menjalankan syari'at Islam di tengahtengah kehidupan umat manusia sebaik-baiknya, 2) berfungsi untuk menciptakan kemaslahatan bersama secara hakiki, lahir dan batin seluruh rakyat, dan 3) merupakan lembaga yang harus bertanggung jawab dalam menjalankan amanah dan menciptakan keadilan. ${ }^{41}$

\section{E. Negara Nubuwwah dan Khilafah Nubuwwah}

Tesis pokok Ibn Taimiyah mengenai negara kenabian adalah bahwa Nabi Muhammad Saw. hanyalah seorang nabi, ia beranggapan bahwa Negara (imamah) bukanlah tujuan kenabian (nubuwwah), bahwa segala aktifitas nabi tercakup ke dalam fungsi kenabiannya, dan bahwa institusi imamah tidak berada di luar fungsi tersebut dan tidak pula merupakan rukun iman. ${ }^{42}$ Dengan sangat tegas ia mengemukakan bahwa iman bukan negara, negara hanyalah sebagai akibat yang perlu dari iman bukan sebaliknya. ${ }^{43}$

Pada masa nabi masih hidup, imamah/Negara tidak diperlukan, konsep imamah muncul setelah nabi wafat. Ibn Taimiyah memiliki alasan-alasan yang kuat untuk membedakan rejim nubuwwah dengan negara Islam yang lahir setelah Nabi Muhammad meninggal dunia. Seorang raja, menurutnya, kepatuhan rakyat kepadanya karena ia adalah seorang raja. Tetapi, kita tentu menyadari bahwa Nabi Muhammad harus dipatuhi bukan karena dia seorang kepala negara tetapi karena

\footnotetext{
${ }^{41}$ Rojak, Politik, hlm. 166-167.

${ }^{42}$ Khan, The Political, hlm. 99.

${ }^{43}$ Ibid.
} 
dia adalah Rasul Allah. ${ }^{44}$ Nabi tidak menerima kekuatan politik dari seorang pun juga, tidak dipilih oleh rakyatny menjadi kepala Negara, dan tidak perlu memberikan pertanggungjawaban kepada mereka, yang perlu diingat, nabi ditaati sesudah wafatnya sebagaimana ditaati pada masa hidupnya, di sinilah yang membedakan rezim nubuwwah dengan imamah. ${ }^{45}$

Sebenarnya inti tesis Ibn Taimiyah di atas dikarenakan pertama, penyangkalannya terhadap teori ilahiah mengenai imamah yang dikemukakan kaum Syi'ah, sedang ia tidak menyangkal fakta sejarah bahwa Nabi Muhammad adalah seorang imam yang sejati. Kedua, menurutnya, kaum Muslim tidak pernah mementingkan sesuatu pun juga melebihi iman. Ketiga, bahwa detail-detail penataan, menegakkan bahwa kekhalifahan/negara tidak mempunyai dasar konstitusional dari al-Quran. Negara, menurutnya, harus dinamis dan progresif di dalam sifat dan kondisinya.

Berkaitan dengan imamah setelah nabi (khilafah an-nubuwwah), Ibn Taimiyah menyatakan bahwa ke empat khalifah Rasyidun (khususnya Abu bakar dan Umar) telah dipilih menjadi khalifah oleh nashsh nabi yang tidak langsung baik langsung atau tidak langsung, dan mereka telah di tolong Allah untuk memberikan teladan yang gemilang dari suatu tata masyarakat Islam. ${ }^{46}$ Lebih lanjut Ibn Taimiyah berkata bahwa dengan berakhirnya rezim ke empat khalifah tersebut, maka berakhir pula rezim khilafah an-nubuwwah dan tidak akan terulang kembali dalam sejarah. ${ }^{47}$

${ }^{44}$ Ibid, hlm. 102-103.

${ }^{45} \mathrm{Ibid}, \mathrm{hlm}$. 304-305.

${ }^{46}$ Pendapat ini dalan hal-hal tertentu sesuai dengan teori Syi'ah dan kekhalifahan bayangan.

${ }^{47} \mathrm{Ibid}, \mathrm{hlm}$. 306-307. 


\section{F. Implikasi Pemikiran Ibn Taimiyah terhadap Pemikiran Politik Islam Modern}

Ibn Taimiyah yang bermadzhab Hambali dalam banyak-meskipun tidak semua- perkara hukum dan teologis, dan seorang penganut Salafiyah pada bidang yang lebih luas, sangat berpengaruh kuat di kalangan Sunni konservatif dan dalam periode modern di kalangan kaum liberal dan konservatif. Sejumlah gagasan Ibn Taimiyah relevan dengan masyarakat dan politik karena menurutnya agama dan negara berkaitan erat (al-Islam al-din wa al-daulah).

Pemikiran politik Ibn Taimiyah -dalam hal pemahamannya yang tidak kaku terhadap konsep khilafah- adalah bentuk negara boleh apa saja asalkan bisa merealisasikan tujuan-tujuan sebuah negara, yaitu kemaslahatan umat manusia, menciptakan keadilan dan menegakkan syariat Allah. Berkaitan dengan konsep kepala negara (khalifah), Ibn Taimiyah memberi peluang bagi adanya pluralisme dalam dunia Islam, di mana pendapatnya bahwa umat Islam tidak harus mempunyai hanya seorang khalifah, tetapi dibolehkan adanya beberapa khalifah dan beberapa negara yang menjadi daerah kekuasaan masing-masing khalifah itu. ${ }^{48}$ Pandangan yang cukup realistis mengingat pada masa Ibn Taimiyah secara de facto tidak hanya terdiri dari satu kekhalifahan, tetapi terdiri dari lebih satu kekhalifahan dan beberapa kerajaan atau dinasti yakni seperti Dinasti Saljuk, Ayyubiyah, Mamluk, dan sampai pada masa kekuasaan Dinasti Mongol-Chaghtai. Terpecah-pecahnya dunia Islam secara geografi adalah sebuah kenyataan; setiap bagian telah menjadi sebuah entitas politik yang berdiri sendiri. Teori klasik mengenai kekhalifahan yang universal tidak dapat menerima dan menghilangkan kenyataan ini. Persatuan umat Islam hanya dapat diwujudkan melalui kerjasama antara entitas-entitas politik baik regional maupun internasional. Jadi tidaklah penting untuk mendesak dunia Islam dalam satu kesatuan politik. ${ }^{49}$ hlm. 42.

${ }^{48}$ Nurcholish Madjid, Khazanah Intelektual Islam (Jakarta: Bulan Bintang, 1994),

${ }^{49}$ Qomaruddin Khan, The Political, hlm. 312.

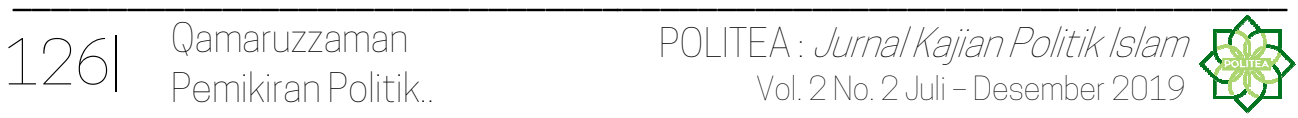




\section{G. Penutup}

Pemikiran politik Ibn Taimiyah begitu penting di dalam sejarah politik Islam, bahkan hingga saat ini. Ibn Taimiyah dengan keberaniannya menghapuskan/penolakan sistem kepemimpinan Khilafah dan Imamah, dengan tesisnya yang mengatakan bahwa rejim yang ditegakkan nabi adalah rejim nubuwwah dan bukan imamah, sedang imamah baru ada setelah nabi wafat menunjukkan bahwa ia mempunyai gagasan yang revolusioner dan pembaruan. Ia tidak ingin rakyat hanya menjadi objek dalam sebuah negara tapi Ia ingin rakyat menjadi subjek atas negara.

Bagi Ibn Taimiyah, mekanisme/sistem pengangkatan kepala negara tidak terlalu penting, yang penting adalah bahwa orang yang menduduki jabatan itu harus benar-benar amanah dan adil. Ibn Taimiyah mensyaratkan dua hal bagi kepala negara, yaitu memiliki kualifikasi kekuatan (al-quwwah) dan integritas (alamanat). Kekuatan dan integritas tersebut diperoleh melalui cara mubaya'ah (sumpah setia) yang diberikan oleh ahl al-Syawkah.

Ibn Taimiyah lebih cenderung kepada bentuk pemerintahan demokratis, hanya saja demokratis yang dikehendaki Ibn Taimiyah adalah demokratis konstitusional yang berlandaskan nilai-nilai syari'at dan berlandaskan keinginan rakyat dan memberikan rakyat ruang untuk berpartisipasi dalam politik. Model seperti ini, menurut Ibn Taimiyah, bisa merealisasikan nilai-nilai keadilan. Pemikirannya ini menurut penulis relevan dan sejalan dengan asas demokrasi yang populer saat ini bahkan bisa berimplikasi menjadi acuan para negarawan untuk membangun sebuah tatanan pemerintahan.

Dengan adanya konsepsi di atas inilah, dapat dirumuskan bahwa praktik kenegaraan bukan atas dasar nas formal (tekstual), akan tetapi berdasarkan kemaslahatan yang dapat dirasakan oleh orang banyak. Dengan demikian, dasar maslahat mempunyai peranan di dalam masalah kenegaraan tersebut. 


\section{DAFTAR PUSTAKA}

Amin, Husayn Ahmad, al-Mi'ah al-A'zham fi Tarikh al-Islam. Cucu Cuanda (ed.) Seratus Tokoh dalam Sejarah Islam, Bandung: Remaja Rosdakarya, cet. 7, 2001.

Amin, Muhammad, Ijtihad Ibn Taimiyah dalam Bidang Fikih Islam, Jakarta: INIS, 1991.

G.P, M. Arskal Salim, Etika Intervensi Negara, Jakarta: Ligos, 1998.

http: //aliboron. wordpress. com/2010/10/26/pemikiran-politik-Ibn-taimiyah

Karim, Abdul, Islam di Asia Tengah; Sejarah Dinasti Mongol-Islam, Yogyakarta: Bagaskara, 2006.

Katsir, Ibn, al-Bidayah wa an-Nihayah, jilid IX juz 14, Beirut Lebanon: Dar al-Fikr, t.th.

Khallaf, Abd al-Wahhab, 'Ilmu Usul al-Fiqh,Kuwait: Dar al-Qalam,1397 H/1997 M.

Khan, Qomaruddin, The Political Thought of Ibn Taymiyyah., terj. Anas Wahyuddin, Pemikiran Politik Ibn Taymiyyah, Bandung: Pustaka, cet. 2, 2001.

Madjid Nurcholish, Khazanah Intelektual Islam, Jakarta: Bulan Bintang, 1994.

Al-Maududi, Political Theory of Islam, Lahore: Islamic Publications Limited, 1960.

Rojak, Jeje Abdul, Politik Kenegaraan Pemikiran al-Ghazali dan Ibn Taimiyah, Surabaya: Bina Ilmu, cet. 1, 1999. 
Sjadzali, Munawir, Islam dan Tata Negara Ajaran, Sejarah dan Pemikiran, edisi 5, Jakarta: UI Press, 1993.

Taimiyah, Ibn, Minhaj al-Sunnah al-Nabawiyah fi Naqd Kalam al-Syiah wa alQadariyah, jilid 1, Kairo: Maktabah Dar al-'Urubat, 1962.

Taimiyah, Ibn, al-Hisbah fi al-Islam au Wadifah al-Hukumah al-Islamiyah, BeirutLibanon: Dar al-Kutub al-Ilmiyah, 1412 H/1992M.

Taimiyah, Ibn, As-Siyasah asy-syar'iyyah fi islah al-Ra'i wa ar-Ra'iyyah, Beirut Lebanon:: Dar al-Kutub al-Ilmiyah, 1409H/1988M.

Taimiyah, Ibn, Siyasah Syar'iyah: Etika Politik Islam” Terj. Rafi' Munawar, Surabaya: Risalah Gusti, 2005.

al-Ustadz Abdul Ghani Hamadah, Fadh al-Dzakirin wa al-Raddu 'Ala al-Munkirin, Suria: t.p., 1971. 